\title{
S.1.
}

Prepared in cooperation with the Indianapolis Department of Public Works and CWA Authority, Inc.

\section{Benthic-Invertebrate, Fish-Community, and Streambed- Sediment-Chemistry Data for Streams in the Indianapolis Metropolitan Area, Indiana, 2009-2012}

Data Series 819 


\section{Cover:}

Image courtesy of Rick Hill, Kentucky Department of Fish and Wildlife Resources. 


\section{Benthic-Invertebrate, Fish-Community, and Streambed-Sediment-Chemistry Data for Streams in the Indianapolis Metropolitan Area, Indiana, 2009-2012}

By David C. Voelker

Prepared in cooperation with the Indianapolis Department of Public Works and CWA Authority, Inc.

Data Series 819 


\title{
U.S. Department of the Interior SALLY JEWELL, Secretary
}

\section{U.S. Geological Survey Suzette M. Kimball, Acting Director}

\author{
U.S. Geological Survey, Reston, Virginia: 2014
}

For more information on the USGS - the Federal source for science about the Earth, its natural and living resources, natural hazards, and the environment, visit http://www.usgs.gov or call 1-888-ASK-USGS.

For an overview of USGS information products, including maps, imagery, and publications, visit http://www.usgs.gov/pubprod

To order this and other USGS information products, visit http://store.usgs.gov

Any use of trade, firm, or product names is for descriptive purposes only and does not imply endorsement by the U.S. Government.

Although this information product, for the most part, is in the public domain, it also may contain copyrighted materials as noted in the text. Permission to reproduce copyrighted items must be secured from the copyright owner.

Suggested citation:

Voelker, D.C., 2014, Benthic-invertebrate, fish-community, and streambed-sediment-chemistry data for streams in the Indianapolis metropolitan area, Indiana, 2009-2012: U.S. Geological Survey Data Series 819, 8 p.,

http://dx.doi.org/10.3133/ds819.

ISSN 2327-638X (online) 


\section{Contents}

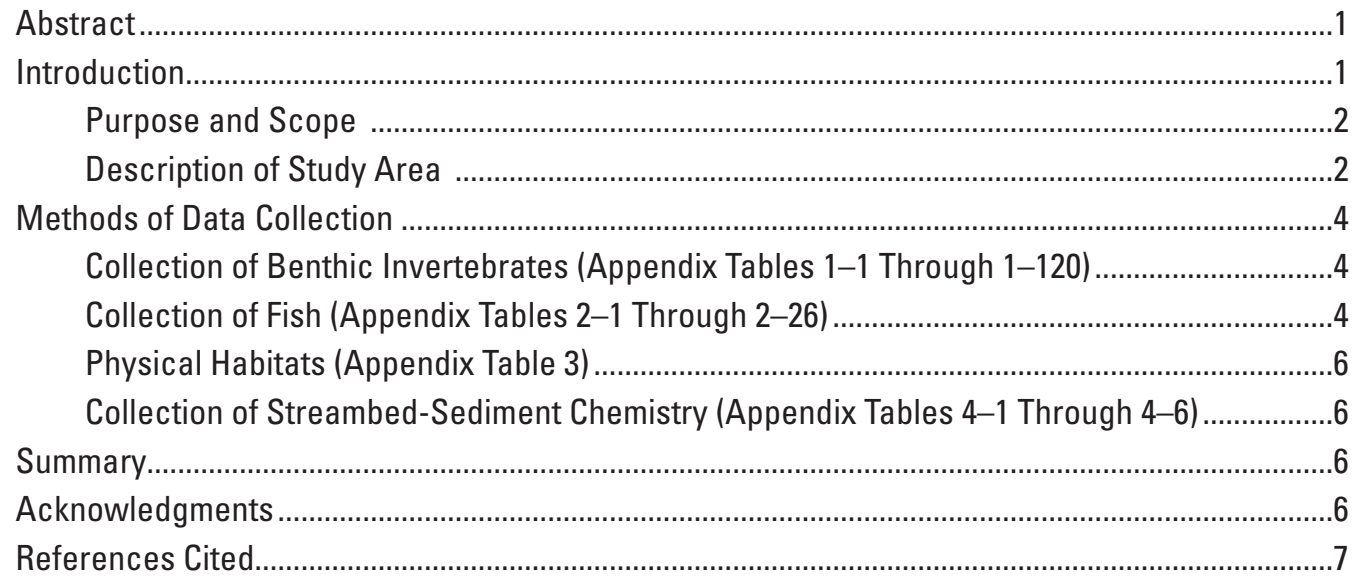

\section{Figures}

1. Map showing location of the study area and site locations on the White River and tributaries in the Indianapolis metropolitan area .3

\section{Tables}

1. Sites sampled for benthic invertebrates, fish communities, and streambed-

sediment chemistry, 2009-2012

\section{Appendixes}

[Appendix tables are available online at http://dx.doi.org/10.3133/ds819.]

\section{Appendix 1}

Tables 1-1 to 1-118. Benthic-invertebrate data for:

July 2009:

1-1. White River near Nora, Ind.

1-2. White River at Morris Street at Indianapolis, Ind.

1-3. White River at Morris Street at Indianapolis, Ind.

1-4. White River at Harding Street at Indianapolis, Ind.

1-5. White River below Stout Generating Station at Indianapolis, Ind.

1-6. White River at Tibbs-Banta Landfill near Southport, Ind.

1-7. White River at Wicker Road near Southport, Ind.

1-8. White River at Waverly, Ind.

1-9. White River at Waverly, Ind. 
1-10. Buck Creek 1.2 miles downstream from Maze Road near Brookfield, Ind.

1-11. Eagle Creek at Raymond Street at Indianapolis, Ind.

1-12. Fall Creek at 16th Street at Indianapolis, Ind.

1-13. Pleasant Run near South Meridian Street at Indianapolis, Ind.

1-14. Pogues Run at Vermont Street at Indianapolis, Ind.

1-15. Williams Creek at 96th Street at Indianapolis, Ind.

September 2009:

1-16. White River near Nora, Ind.

1-17. White River at Morris Street at Indianapolis, Ind.

1-18. White River at Harding Street at Indianapolis, Ind.

1-19. White River at Harding Street at Indianapolis, Ind.

1-20. White River below Stout Generating Station at Indianapolis, Ind.

1-21. White River at Tibbs-Banta Landfill near Southport, Ind.

1-22. White River at Wicker Road near Southport, Ind.

1-23. White River at Waverly, Ind.

1-24. Buck Creek 1.2 miles downstream from Maze Road near Brookfield, Ind.

1-25. Eagle Creek at Raymond Street at Indianapolis, Ind.

1-26. Fall Creek at 16 th Street at Indianapolis, Ind.

1-27. Pleasant Run near South Meridian Street at Indianapolis, Ind.

1-28. Pogues Run at Vermont Street at Indianapolis, Ind.

1-29. Williams Creek at 96th Street at Indianapolis, Ind.

1-30. Williams Creek at 96th Street at Indianapolis, Ind.

July-August 2010:

1-31. White River near Nora, Ind.

1-32. White River near Nora, Ind.

1-33. White River at Morris Street at Indianapolis, Ind.

1-34. White River at Harding Street at Indianapolis, Ind.

1-35. White River below Stout Generating Station at Indianapolis, Ind.

1-36. White River at Tibbs-Banta Landfill near Southport, Ind.

1-37. White River at Wicker Road near Southport, Ind.

1-38. White River at Waverly, Ind.

1-39. Buck Creek 1.2 miles downstream from Maze Road near Brookfield, Ind.

1-40. Buck Creek 1.2 miles downstream from Maze Road near Brookfield, Ind.

1-41. Eagle Creek at Raymond Street at Indianapolis, Ind.

1-42. Fall Creek at 16th Street at Indianapolis, Ind.

1-43. Pleasant Run near South Meridian Street at Indianapolis, Ind.

1-44. Pogues Run at Vermont Street at Indianapolis, Ind.

1-45. Williams Creek at 96 th Street at Indianapolis, Ind.

September 2010:

1-46. White River near Nora, Ind.

1-47. White River at Morris Street at Indianapolis, Ind.

1-48. White River at Morris Street at Indianapolis, Ind.

1-49. White River at Harding Street at Indianapolis, Ind. 
1-50. White River below Stout Generating Station at Indianapolis, Ind.

1-51. White River at Tibbs-Banta Landfill near Southport, Ind.

1-52. White River at Wicker Road near Southport, Ind.

1-53. White River at Waverly, Ind.

1-54. Buck Creek 1.2 miles downstream from Maze Road near Brookfield, Ind.

1-55. Buck Creek 1.2 miles downstream from Maze Road near Brookfield, Ind.

1-56. Eagle Creek at Raymond Street at Indianapolis, Ind.

1-57. Eagle Creek at Raymond Street at Indianapolis, Ind.

1-58. Fall Creek at 16th Street at Indianapolis, Ind.

1-59. Pleasant Run near South Meridian Street at Indianapolis, Ind.

1-60. Williams Creek at 96 th Street at Indianapolis, Ind.

July 2011:

1-61. White River near Nora, Ind.

1-62. White River at Morris Street at Indianapolis, Ind.

1-63. White River at Harding Street at Indianapolis, Ind.

1-64. White River at Harding Street at Indianapolis, Ind.

1-65. White River below Stout Generating Station at Indianapolis, Ind.

1-66. White River at Tibbs-Banta Landfill near Southport, Ind.

1-67. White River at Wicker Road near Southport, Ind.

1-68. White River at Waverly, Ind.

1-69. Buck Creek 1.2 miles downstream from Maze Road near Brookfield, Ind.

1-70. Eagle Creek at Raymond Street at Indianapolis, Ind.

1-71. Fall Creek at 16th Street at Indianapolis, Ind.

1-72. Pleasant Run near South Meridian Street at Indianapolis, Ind.

1-73. Pleasant Run near South Meridian Street at Indianapolis, Ind.

1-74. Pogues Run at Vermont Street at Indianapolis, Ind.

1-75. Williams Creek at 96 th Street at Indianapolis, Ind.

Fall 2011:

1-76. White River near Nora, Ind.

1-77. White River at Morris Street at Indianapolis, Ind.

1-78. White River at Harding Street at Indianapolis, Ind.

1-79. White River below Stout Generating Station at Indianapolis, Ind.

1-80. White River below Stout Generating Station at Indianpolis, Ind.

1-81. White River at Tibbs-Banta Landfill near Southport, Ind.

1-82. White River at Wicker Road near Southport, Ind.

1-83. White River at Waverly, Ind.

1-84. Buck Creek 1.2 miles downstream from Maze Road near Brookfield, Ind.

1-85. Eagle Creek at Raymond Street at Indianapolis, Ind.

1-86. Fall Creek at 16th Street at Indianapolis, Ind.

1-87. Pleasant Run near South Meridian Street at Indianapolis, Ind.

1-88. Pleasant Run near South Meridian Street at Indianapolis, Ind.

1-89. Pogues Run at Vermont Street at Indianapolis, Ind.

1-90. Williams Creek at 96th Street at Indianapolis, Ind. 
Spring 2012:

1-91. White River near Nora, Ind.

1-92. White River at Morris Street at Indianapolis, Ind.

1-93. White River at Harding Street at Indianapolis, Ind.

1-94. White River below Stout Generating Station at Indianapolis, Ind.

1-95. White River at Tibbs-Banta Landfill near Southport, Ind.

1-96. White River at Tibbs-Banta Landfill near Southport, Ind.

1-97. White River at Wicker Road near Southport, Ind.

1-98. White River at Waverly, Ind.

1-99. Buck Creek 1.2 miles downstream from Maze Road near Brookfield, Ind.

1-100. Eagle Creek at Raymond Street at Indianapolis, Ind.

1-101. Fall Creek at 16th Street at Indianapolis, Ind.

1-102. Pleasant Run near South Meridian Street at Indianapolis, Ind.

1-103. Pogues Run at Vermont Street at Indianapolis, Ind.

1-104. Pogues Run at Vermont Street at Indianapolis, Ind.

1-105. Williams Creek at 96th Street at Indianapolis, Ind.

Fall 2012:

1-106. White River near Nora, Ind.

1-107. White River at Morris Street at Indianapolis, Ind.

1-108. White River at Harding Street at Indianapolis, Ind.

1-109. White River below Stout Generating Station at Indianapolis, Ind.

1-110. White River at Tibbs-Banta Landfill near Southport, Ind.

1-111. White River at Wicker Road near Southport, Ind.

1-112. White River at Wicker Road near Southport, Ind.

1-113. White River at Waverly, Ind.

1-114. Buck Creek 1.2 miles downstream from Maze Road near Brookfield, Ind.

1-115. Eagle Creek at Raymond Street at Indianapolis, Ind.

1-116. Fall Creek at 16th Street at Indianapolis, Ind.

1-117. Pleasant Run near South Meridian Street at Indianapolis, Ind.

1-118. Pogues Run at Vermont Street at Indianapolis, Ind.

1-119. Williams Creek at 96 th Street at Indianapolis, Ind.

1-120. Williams Creek at 96th Street at Indianapolis, Ind.

Appendix 2

Tables 2-1 to 2-26. Fish-community data for:

2010:

2-1. White River near Nora, Ind.

2-2. White River at Morris Street at Indianapolis, Ind.

2-3. White River at Harding Street at Indianapolis, Ind.

2-4. White River below Stout Generating Station at Indianapolis, Ind.

2-5. White River at Tibbs-Banta Landfill near Southport, Ind.

2-6. White River at Wicker Road near Southport, Ind.

2-7. White River at Waverly, Ind. 
2-8. Buck Creek 1.2 miles downstream from Maze Road near Brookfield, Ind.

2-9. Eagle Creek at Raymond Street at Indianapolis, Ind.

2-10. Fall Creek at 16th Street at Indianapolis, Ind.

2-11. Pleasant Run near South Meridian Street at Indianapolis, Ind.

2-12. Pogues Run at Vermont Street at Indianapolis, Ind.

2-13. Williams Creek at 96th Street at Indianapolis, Ind.

2012:

2-14. White River near Nora, Ind.

2-15. White River at Morris Street at Indianapolis, Ind.

2-16. White River at Harding Street at Indianapolis, Ind.

2-17. White River below Stout Generating Station at Indianapolis, Ind.

2-18. White River at Tibbs-Banta Landfill near Southport, Ind.

2-19. White River at Wicker Road near Southport, Ind.

2-20. White River at Waverly, Ind.

2-21. Buck Creek 1.2 miles downstream from Maze Road near Brookfield, Ind.

2-22. Eagle Creek at Raymond Street at Indianapolis, Ind.

2-23. Fall Creek at 16th Street at Indianapolis, Ind.

2-24. Pleasant Run near South Meridian Street at Indianapolis, Ind.

2-25. Pogues Run at Vermont Street at Indianapolis, Ind.

2-26. Williams Creek at 96th Street at Indianapolis, Ind.

Appendix 3

Table 3-1. Habitat characteristics for benthic-invertebrate and fish-community sampling sites in the Indianapolis metropolitan area, Indiana, 2010 and 2012.

Appendix 4

Table 4-1 to 4-6. Streambed-sediment chemistry data:

4-1. Physical water-quality properties for sites on the White River and selected tributaries in the Indianapolis metropolitan area, Indiana, 2009 and 2011.

4-2. Carbon-species concentrations in streambed sediments for sites on the White River and selected tributaries in the Indianapolis metropolitan area, Indiana, 2009 and 2011.

4-3. Chlorinated pesticide concentrations in streambed sediments for sites on the White River and selected tributaries in the Indianapolis metropolitan area, Indiana, 2009 and 2011.

4-4. Organophosphate pesticide concentrations in streambed sediments for sites on the White River and selected tributaries in the Indianapolis metropolitan area, Indiana, 2009 and 2011.

4-5. Concentrations of inorganic constituents in streambed sediments for sites on the White River and selected tributaries in the Indianapolis metropolitan area, Indiana, 2009 and 2011.

4-6. Semivolatile organic carbon concentrations in streambed sediments for sites on the White River and selected tributaries in the Indianapolis metropolitan area, Indiana, 2009 and 2011. 


\section{Conversion Factors}

\begin{tabular}{|c|c|c|}
\hline Multiply & By & To obtain \\
\hline \multicolumn{3}{|c|}{ Length } \\
\hline mile (mi) & 1.609 & kilometer (km) \\
\hline \multicolumn{3}{|c|}{ Area } \\
\hline square mile $\left(\mathrm{mi}^{2}\right)$ & 2.590 & square kilometer $\left(\mathrm{km}^{2}\right)$ \\
\hline \multicolumn{3}{|c|}{ Flow rate } \\
\hline cubic foot per second $\left(\mathrm{ft}^{3} / \mathrm{s}\right)$ & 0.02832 & cubic meter per second $\left(\mathrm{m}^{3} / \mathrm{s}\right)$ \\
\hline million gallons per day (Mgal/d) & 0.04381 & cubic meter per second $\left(\mathrm{m}^{3} / \mathrm{s}\right)$ \\
\hline \multicolumn{3}{|l|}{ SI to Inch/Pound } \\
\hline Multiply & By & To obtain \\
\hline \multicolumn{3}{|c|}{ Length } \\
\hline centimeter $(\mathrm{cm})$ & 0.3937 & inch (in.) \\
\hline millimeter $(\mathrm{mm})$ & 0.03937 & inch (in.) \\
\hline meter $(\mathrm{m})$ & 3.281 & foot $(\mathrm{ft})$ \\
\hline micrometer $(\mu \mathrm{m})$ & 0.00003937 & inch (in.) \\
\hline \multicolumn{3}{|c|}{ Area } \\
\hline square meter $\left(\mathrm{m}^{2}\right)$ & 10.76 & square foot $\left(\mathrm{ft}^{2}\right)$ \\
\hline \multicolumn{3}{|c|}{ Mass } \\
\hline $\operatorname{gram}(\mathrm{g})$ & 0.03527 & ounce, avoirdupois (oz) \\
\hline kilogram (kg) & 2.205 & pound avoirdupois (lb) \\
\hline
\end{tabular}

Temperature in degrees Celsius $\left({ }^{\circ} \mathrm{C}\right)$ may be converted to degrees Fahrenheit $\left({ }^{\circ} \mathrm{F}\right)$ as follows: ${ }^{\circ} \mathrm{F}=\left(1.8 \mathrm{x}^{\circ} \mathrm{C}\right)+32$

Specific conductance is given in microsiemens per centimeter at 25 degrees Celsius $\left(\mu \mathrm{S} / \mathrm{cm}\right.$ at $\left.25^{\circ} \mathrm{C}\right)$.

Concentrations of chemical constituents in bed sediments are given either in grams per kilogram $(\mathrm{g} / \mathrm{Kg})$ or micrograms per kilogram $(\mu \mathrm{g} / \mathrm{Kg})$.

Concentrations of dissolved oxygen in water are given as milligrams per liter (mg/L). 


\section{Abbreviations and Acronyms used in this report:}

$\begin{array}{ll}\text { CSO } & \text { Combined-sewer overflow } \\ \text { CSS } & \text { Combined-sewer system } \\ \text { DPW } & \text { Department of Public Works (Indianapolis) } \\ \text { EPT } & \text { Ephemeroptera, Plecoptera, and Trichoptera Index } \\ \text { HBI } & \text { Hilsenhoff Biotic Index } \\ \text { IN-WSC } & \text { Indiana Water Science Center } \\ \text { MGD } & \text { Million gallons per day (Mgal/d) } \\ \text { NAWQA } & \text { National Water Quality Assessment Program } \\ \text { NWOL } & \text { National Water Quality Laboratory } \\ \text { PCB } & \text { Polychlorinated biphenyls } \\ \text { OHEI } & \text { Qualitative Habitat Evaluation Index } \\ \text { USEPA } & \text { U.S. Environmental Protection Agency } \\ \text { USGS } & \text { U.S. Geological Survey } \\ \text { WWTF } & \text { Wastewater treatment facility }\end{array}$





\title{
Benthic-Invertebrate, Fish-Community, and Streambed- Sediment-Chemistry Data for Streams in the Indianapolis Metropolitan Area, Indiana, 2009-2012
}

\author{
By David C. Voelker
}

\begin{abstract}
Aquatic-biology and sediment-chemistry data were collected at seven sites on the White River and at six tributary sites in the Indianapolis metropolitan area of Indiana during the period 2009 through 2012. Data collected included benthic-invertebrate and fish-community information and concentrations of metals, insecticides, herbicides, and semivolatile organic compounds adsorbed to streambed sediments. A total of 120 benthic-invertebrate samples were collected, of which 16 were replicate samples. A total of 26 fish-community samples were collected in 2010 and 2012. Thirty streambedsediment chemistry samples were collected in 2009 and 2011, of which four were concurrent duplicate samples.
\end{abstract}

\section{Introduction}

Approximately 41 square miles $\left(\mathrm{mi}^{2}\right)$ of Indianapolis, Indiana (Ind.), is serviced by a combined-sewer system (CSS) that is designed, constructed, and operated to carry both sanitary sewage and stormwater runoff in the same system. Diversion structures within the CSS route sanitary sewage to the wastewater treatment facility (WWTF) during dry weather; but during wet weather, the CSSs often discharge directly into surface water via combined-sewer overflow (CSO) outfalls (State of Indiana, 1996). The Indianapolis Department of Public Works (DPW) managed the CSS until October 25, 2011, at which time CWA Authority, Inc. took control of operations and is now managing the sewer system in the Indianapolis metropolitan area. The sewer-system operator is responsible for implementing control strategies to mediate the effects of CSOs on water quality of receiving streams in and around Marion County, Ind., including Indianapolis.

Receiving waters in the study area for CSO and WWTF effluent include the White River and several of its tributaries: Pogues Run, Pleasant Run, Eagle Creek, and Fall Creek. Williams Creek and Buck Creek are tributaries that do not have
CSO inputs but can be subject to input from septic systems or sanitary-sewer failures. The most upstream site on the White River, Nora, is not affected by Indianapolis CSOs, although several WWTFs discharge to the White River upstream from this site.

The U.S. Environmental Protection Agency (USEPA) (1999), in a guidance document for monitoring and modeling of CSOs, states that baseline water-quality conditions of the receiving waters need to be defined. The DPW previously, and CWA Authority, Inc. currently, have programs to collect and analyze surface-water samples within Marion County; however, if water-quality samples are used as the sole method to determine water quality, substantial effects on the biological communities between sampling such as habitat degradation, siltation, and flow alterations can be missed. Therefore, biological indicators to monitor the overall health of the White River within Marion County, Ind., and its tributaries also were included in the monitoring programs (City of Indianapolis, 2000).

Biological criteria complement water-quality programs that focus on direct measures of water chemistry and physical properties of the aquatic environment. Many stream biota complete most, or all, of their life cycles in the water, thereby serving as continuous monitors of environmental quality. Biological criteria can indicate water-quality impairments, provide data in support of regulatory controls that address water-quality problems, and assess improvements in water quality from regulatory efforts. Benthic-invertebrate and fish-community assessments are used as measures of biotic integrity in streams. Benthic invertebrates have limited mobility and can be used as indicators of the long-term effects of water quality in streams. Benthic invertebrates can be found in all but the most severely polluted habitats. Fish communities, although much more mobile than benthic invertebrates, can also be used to evaluate water-quality conditions in a stream. Benthic invertebrate and fish communities are sensitive to a wide variety of environmental factors such as habitat 
degradation, siltation, pesticides, nutrients, and alterations in streamflow. Fish may also be absent from a stream because of natural or manmade causes such as dams or shallow riffles that obstruct their passage along a stream reach. Diversity among these communities can be affected by colonization rates, the presence of suitable habitat, extinction rates, competition, predation, physical disturbances, pollution, and other factors (Crowder, 1990).

Streambed-sediment chemistry was investigated to complement the biological data collected by the U.S. Geological Survey (USGS) and surface-water-quality data, formerly collected by the DPW Office of Environmental Services, and since October 2012, collected by CWA Authority, Inc. Analysis of streambed-sediment samples can help determine what chemical constituents were adsorbed to sediment in the White River and several of its tributaries in the Indianapolis metropolitan area. These data could potentially help explain differences in the biological communities at each site. Streambed sediments are important to biological communities both as habitat and as a food source. The benthic organic matter in sediment can adsorb many hydrophobic anthropogenic compounds, and these compounds may become biologically available to benthic organisms through exposure to, or ingestion of, contaminated sediment (Landrum and Robbins, 1990; Benke and Wallace, 1997). Mortality of aquatic invertebrates can be high in urban streams and can indicate possible toxicity associated with streambed-sediment exposure or ingestion of toxins associated with the sediments (Pratt and others, 1981; Medeiros and others, 1983).

Rochfort and others (2000) indicate that runoff from urban areas, including municipal wastewater discharge, produces increased contaminant loads to streams, and a decline in the numbers of taxa (richness) of biological communities in urban streams often results. Chemical effects of urbanization are variable and depend on the type of urbanization, presence of WWTF effluents and (or) CSOs, and the extent of stormwater drainage (Paul and Meyer, 2001). Urbanization is second only to agriculture as the major cause of stream impairment (Paul and Meyer, 2001).

Data collected for this project add to and complement data collected by prior cooperative studies between the DPW and USGS, as well as the monthly chemical monitoring of surface waters previously done by the DPW and now by CWA Authority, Inc.. In the early 1980s, the USGS, in cooperation with the DPW, began a study to assess changes in the benthic-invertebrate communities in the White River in response to changes and upgrades in Indianapolis WWTFs (Crawford and others, 1992). In the 1990s a second study was begun to assess biological communities and streambedsediment chemistry in the White River and selected tributaries relative to CSO issues that the City of Indianapolis was assessing (Renn, 1998; Voelker and Renn, 2000). In 1999-2001, a third study was conducted that assessed benthic-invertebrate and fish communities (Voelker, 2004). During 2003 and 2004, collection of benthic invertebrate samples resumed, and during 2005-2008, an additional 4-year cooperative study ensued in which benthic-invertebrate, fish-community, and streambedsediment-chemistry data were collected (Voelker, 2012). The biological condition of these streams reflects the overall effect from all sources entering the receiving waters and cannot be attributed solely to effects from CSOs.

\section{Purpose and Scope}

This report summarizes the data collected during 20092012 for this study. Data collected include (1) the diversity and density of benthic invertebrates, (2) the diversity of the fish communities, and (3) the concentrations of metals, insecticides, herbicides, and semivolatile organic compounds adsorbed to streambed sediments. From 2009 through 2012, a total of 120 benthic-invertebrate samples were collected, of which 16 were replicate samples. A total of 26 fish-community samples were collected in 2010 and 2012, and 30 streambedsediment chemistry samples were collected in 2009 and 2011, of which 4 were concurrent duplicate samples.

\section{Description of Study Area}

Indianapolis is the capital of Indiana and the largest city in the State. The city is incorporated with Marion County and covers approximately $402 \mathrm{mi}^{2}$. Approximately $41 \mathrm{mi}^{2}$ are served by a CSO system (fig. 1) (City of Indianapolis, 2007). In 2007, this system had approximately 130 CSOs that discharged into the White River directly or into several of its tributaries. The remaining sewer system in Indianapolis uses separate sanitary and storm sewers and covers slightly more than $200 \mathrm{mi}^{2}$. The rest of Indianapolis not served by CSOs uses private septic systems, but most of these areas are gradually being converted to sanitary sewers (City of Indianapolis, 2007).

The study area is in the Central climate division in Indiana, which is characterized by hot, humid summers and cold, wet winters (Newman, 1966). Physiographically, the study area is within the Eastern Corn Belt Plains ecoregion (Woods and others, 1998). Crop production, primarily corn and soybeans, is the predominant land use outside of the urban areas of Indianapolis (Simon and Dufour, 1997).

Thirteen sites were sampled in the study area, of which seven are on the White River and six are on tributaries to the White River (table 1). Most sites were selected to coincide with sites used by DPW and CWA Authority, Inc. for monthly water-quality sampling.

Voelker $(2004,2012)$ described sampling locations and conditions for the sites used in this study. Seven are located along the White River as it flows through Marion County and into Morgan County (fig. 1). Nora, the most upstream site on the White River, is the only one upstream of the CSO-served areas and upstream of the Indianapolis WWTFs. 


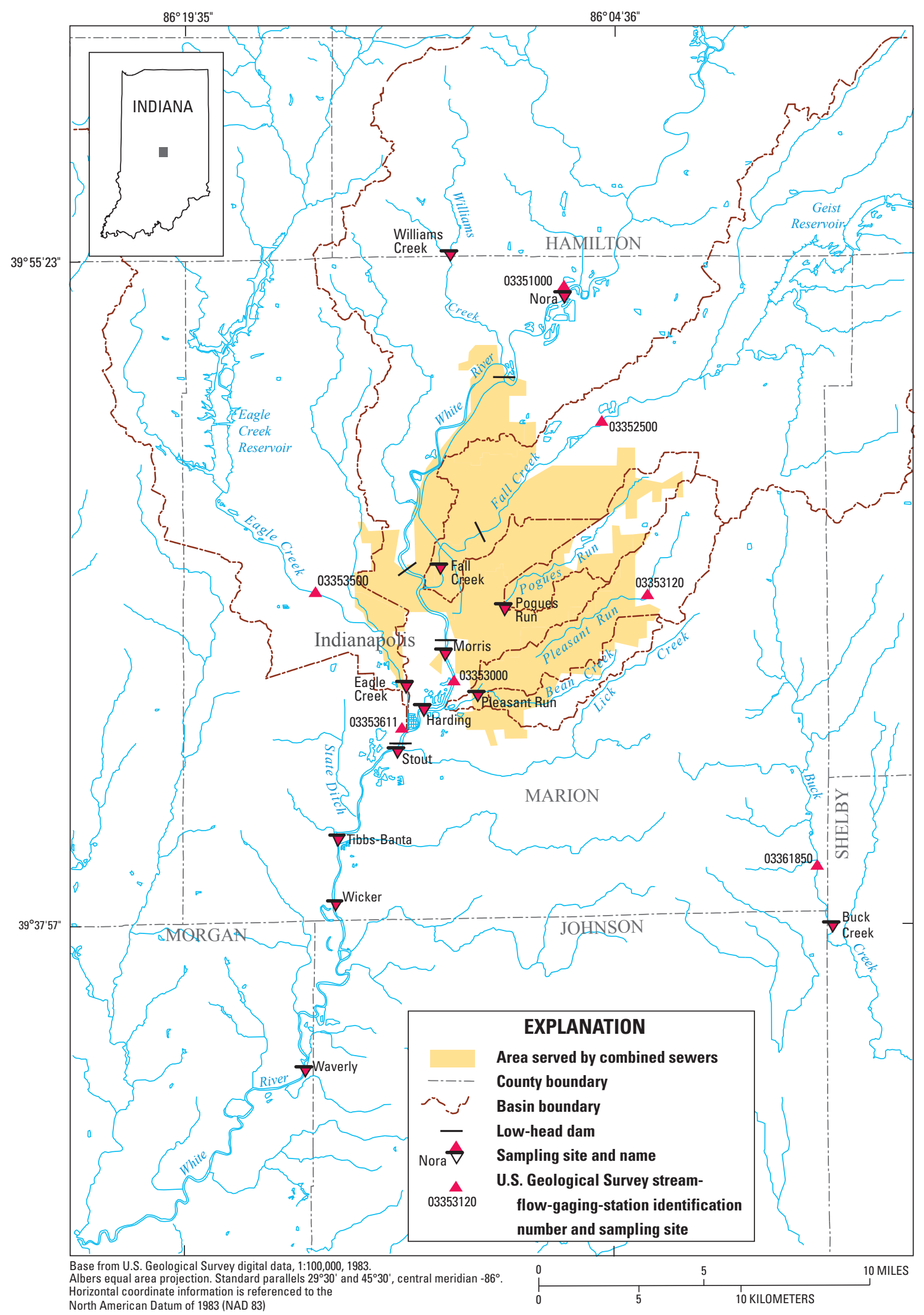

Figure 1. Location of the study area and site locations on the White River and tributaries in the Indianapolis metropolitan area. 
Six sites are located on tributaries in and around Marion County (fig. 1). Two of those sites (Buck Creek and Williams Creek) are outside the CSO-served area. The remaining four tributary sites all receive input from CSOs, although the number and volume of such overflows varies by drainage basin (Voelker, 2004). Pleasant Run has the most CSOs (49), followed by Fall Creek (27), Pogues Run (24), and Eagle Creek (5). Pogues Run is the only site with observed periods of no flow during the late-summer sampling periods.

The total drainage area of the White River is $5,372 \mathrm{mi}^{2}$ at the confluence with the East Fork White River. At the most downstream site sampled (Waverly) the drainage area is 2,026 $\mathrm{mi}^{2}$. The drainage area at the most upstream site sampled (Nora) is $1,219 \mathrm{mi}^{2}$ (Hoggatt, 1975) (table 1). In addition to the CSOs, large inputs to the White River include discharges from the Belmont and Southport WWTFs in the southern reaches of the study area and the Carmel WWTF approximately 3 river miles upstream from the Nora site. The Belmont WWTF has a capacity of 120 million gallons per day $\left(\mathrm{MGD}^{1}\right)$, with peak flows up to $300 \mathrm{MGD}$. The Southport WWTF has a capacity of 125 MGD, with peak flows to 180 MGD. Together, the two Indianapolis WWTFs treat over 70 billion gallons of wastewater each year (City of Indianapolis, 2007).

\section{Methods of Data Collection}

During this study, benthic-invertebrate samples were collected biannually at each site, except for fall 2010 when Pogues Run was dry and no sample was collected. Fish-community data were collected at each site during 2010 and 2012. Streambed sediments were collected twice during the study period - in 2009 and in 2011 - to assess chemical constituents that may affect the biological communities at the study sites.

\section{Collection of Benthic Invertebrates (Appendix Tables 1-1 Through 1-120)}

Benthic invertebrates were collected twice a year during periods of relatively stable low streamflow. Samples were collected in the spring (May through July) and again in the late summer/early fall (September through October). Higher than normal discharges on occasion resulted in delayed sampling events so that benthic invertebrate samples could be collected during periods of relatively stable low flow. Three individual benthic invertebrate samples were collected at each site from habitats where the greatest diversity and abundance of invertebrates was expected. These were usually riffle sections; however, those sections were not available at all sites, so then the best available habitat was sampled. This was true of the Harding Street site, where the White River was at very low velocities during benthic invertebrate sampling periods.

\footnotetext{
${ }^{1}$ Also abbreviated Mgal/d. The form "MGD" is the more commonly used by water- and sewage-utility personnel.
}

The three benthic invertebrate samples were collected at each site by using a Surber sampler that had a 0.0929-squaremeter sample grid and a collection-net mesh opening of 210 micrometers $(\mu \mathrm{m})$. Sampling followed the guidelines set forth in Britton and Greeson (1989) and described in Voelker (2004). Duplicate samples were collected at two sites each sample round. During the September 2010 sampling period, Pogues Run was dry, and no sample was collected. In place of the sample from Pogues Run during dry conditions, a third site was selected from among the other sites for replicate sampling during that round.

Benthic invertebrates were preserved and sent to a biological laboratory (Pennington and Associates, Cookeville, Tennessee) where they were identified to the lowest possible taxon-generally genus and species. For this study, ambiguous taxa (labled "unidentified" in tables) were those that could not be identified to species, and these were counted as distinct taxa only if there were no reported individuals from the next highest taxonomic level. Possible reasons for the inability to classify an organism to species may have been that the organism was damaged in the sampling process or that the life stage could not be classified to a lower taxon. The laboratory also calculated the Hilsenhoff Biotic Index (HBI) for each set of three samples. The HBI was calculated from pollutiontolerance values assigned to benthic invertebrate taxa, using the number of individuals in each family and a tolerance value for that family, summing the products, and dividing that sum by the total number of arthropods in the sample (Hilsenhoff, 1987). Scores can range from zero to 10 and increase with presumed organic contamination. The Ephemeroptera, Plecoptera, and Trichoptera (EPT) index was also calculated. The EPT index is merely the sum of the distinct taxa collected in each of those taxonomic orders.

\section{Collection of Fish (Appendix Tables 2-1 Through 2-26)}

Fish communities were sampled during the summer months in 2010 and 2012 in accordance with guidelines established by the USGS National Water-Quality Assessment (NAWQA) Program (Meador and others, 1993) and described in the Indiana Water Science Center quality-assurance plan for fish taxonomic data (Brian Caskey, U.S. Geological Survey, written commun., 2011). At sites on the White River, stream reaches of 500 meters (m) in length were sampled, and at sites on the tributaries, stream reaches were $150 \mathrm{~m}$ in length. Samples were collected as much as practical between riffle cross sections because riffle sections serve as natural barriers to fish migration out of the study reach. Fish were collected by using pulsed direct-current electrofishing techniques. Specially designed electrofishing boats were used at nonwadeable sites (all White River sites), and backpack or tote-barge mounted equipment was used at wadeable stream sites (all tributaries). Two passes were made through each site to sample the fish community. After each pass was completed, the collected fish 
Table 1. Sites sampled for benthic invertebrates, fish communities, and streambed-sediment chemistry, 2009-2012.

[USGS, U.S. Geological Survey; ddmmss, degrees minutes seconds; Ind., Indiana; nr, near; mi, miles; DS, downstream]

\begin{tabular}{|c|c|c|c|c|c|c|c|c|}
\hline \multirow[b]{2}{*}{ Station name } & \multirow[b]{2}{*}{$\begin{array}{c}\text { USGS } \\
\text { station number }\end{array}$} & \multirow[b]{2}{*}{$\begin{array}{l}\text { Latitude } \\
\text { (ddmmss) }\end{array}$} & \multirow[b]{2}{*}{$\begin{array}{l}\text { Longitude } \\
\text { (ddmmss) }\end{array}$} & \multirow[b]{2}{*}{$\begin{array}{l}\text { River } \\
\text { mile }\end{array}$} & \multirow[b]{2}{*}{$\begin{array}{c}\text { Drainage } \\
\text { area } \\
\text { (square miles) }\end{array}$} & \multicolumn{3}{|c|}{ Year first sampled } \\
\hline & & & & & & Benthics & Fish & $\begin{array}{c}\text { Bed } \\
\text { sediment }\end{array}$ \\
\hline \multicolumn{9}{|c|}{ White River (boat sites) } \\
\hline White River near Nora ${ }^{1}$, Ind. & 03351000 & 395435 & -860620 & 247.9 & 1,219 & 1981 & 1999 & 1994 \\
\hline White River at Morris Street, Indianapolis, Ind. & 394505086103001 & 394515 & -861026 & 230.3 & 1,635 & 1994 & 1999 & 1994 \\
\hline White River at Harding Street, Indianapolis, Ind. & 03353193 & 394505 & -861030 & 227.9 & 1,660 & 1994 & 1999 & 1994 \\
\hline White River below Stout Generating Station, Indianapolis, Ind. & 394234086120900 & 394234 & -861209 & 226.2 & 1,898 & 1981 & 1999 & 1995 \\
\hline White River at Tibbs/Banta Landfill near Southport, Ind. & 394019086134601 & 394019 & -861346 & 222.5 & 1,920 & 1994 & 2005 & 1994 \\
\hline White River at Wicker Road near Southport, Ind. & 393827086141701 & 393827 & -861417 & 220.2 & 1,947 & 1994 & 1999 & 1994 \\
\hline White River at Waverly, Ind. & 03353660 & 393402 & -861518 & 211.0 & 2,026 & 1981 & 1999 & 1994 \\
\hline \multicolumn{9}{|c|}{ Tributaries: Wadeable sites } \\
\hline Eagle Creek at Raymond Street, Indianapolis, Ind. & 394613086114700 & 394411 & -861148 & 1.2 & 209 & 1994 & 1999 & 1994 \\
\hline Fall Creek at 16th Street, Indianapolis, Ind. & 03352875 & 394720 & -861040 & 1.3 & 317 & 1994 & 1999 & 1994 \\
\hline Pleasant Run nr South Meridian Street, Indianapolis, Ind. & 394358086092100 & 394358 & -860921 & 1.2 & 20.8 & 1994 & 1999 & 1994 \\
\hline Pogues Run at Vermont Street, Indianapolis, Ind. & 03352990 & 394617 & -860825 & 2.5 & 8.87 & 1994 & 1999 & 1994 \\
\hline \multicolumn{9}{|c|}{ Tributaries: Headwater sites } \\
\hline Buck Creek 1.2 mi DS Maze Road near Brookfield, Ind. & 393749086030501 & 394617 & -860825 & 1.9 & 81.9 & 1999 & 2000 & 2005 \\
\hline Williams Creek at 96th Street, Indianapolis, Ind. & 03351072 & 395537 & -861020 & 4.8 & 17 & 1994 & 1999 & 1994 \\
\hline
\end{tabular}

${ }^{1}$ Short name used throughout text to identify sites is in bold type. 
were identified to the species level, measured, and weighed, and any external anomalies were identified and recorded. Voucher specimens were collected to provide a reference for fish taxonomic classifications made by this study. Voucher specimens were collected either photographically or in a 10-percent formalin preservative and returned to the USGS Indiana Water Science Center (IN-WSC) laboratory (Indianapolis, Ind.). Taxonomic nomenclature used to identify the fish followed that established by Nelson and others (2004).

\section{Physical Habitats (Appendix Table 3)}

During the fish-sampling period, physical characteristics of the sites were documented by using parameters developed by the Ohio Environmental Protection Agency (1989a, 1989b) to compute a Qualitative Habitat Evaluation Index (QHEI). Stream characteristics collected included drainage area, land use, mean discharge, stream gradient, and basin description. Habitat characteristics include substrate; silt cover; extent of substrate embeddedness; instream cover; channel morphology; riparian zone; bank erosion; and pool, riffle, and run information.

\section{Collection of Streambed-Sediment Chemistry (Appendix Tables 4-1 Through 4-6)}

Streambed sediments were collected following the guidelines set forth by Shelton and Capel (1994) and Radtke (2005). Samples were collected during stable low-flow conditions in the summers of 2009 and 2011. Polypropylene scoops were used to collect the topmost layer of wetted fine sediments. These were placed into a glass jar for transport back to the USGS IN-WSC laboratory. At the IN-WSC laboratory, sediment samples were split and sieved into two components: a $63-\mu \mathrm{m}$ fraction to be analyzed for trace elements and a 2-millimeter fraction to be analyzed for organic constituents. The organic-constituent samples were then shipped to the USGS National Water Quality Laboratory (NWQL) and the traceelement samples to the Mineral Resource Program Laboratory in Denver, Colorado, for analysis.

\section{Summary}

The U.S. Geological Survey, along with the Indianapolis Department of Public Works (DPW) and CWA Authority, Inc., maintained a cooperative program during 2009 through 2012 to assess biological communities and streambed-sediment chemistry in the White River and selected tributaries in the Indianapolis metropolitan area. Thirteen sites (seven on the White River and six on tributaries) were sampled biannually for benthic invertebrates and in alternating years for fish communities or streambed-sediment chemistry. This study continued a long-term cooperative program between the agencies to collect biological and streambed sediment data and complements the DPW surface-water monitoring program. The information gathered is being used in connection with CWA Authority, Inc. and Indianapolis to reduce combined sewer overflows (CSOs) and other point and nonpoint sources of pollution in the Indianapolis area.

During this study, benthic invertebrate samples were collected biannually at each site except for fall 2010, when Pogues Run was dry and no sample was collected there. Fish-community data were collected at each site during 2010 and 2012. Streambed sediments were collected twice during the study period - in 2009 and in 2011 - to assess chemical constituents that may affect the biological communities at the study sites.

\section{Acknowledgments}

The author thanks everyone who assisted in the timely and successful completion of this project. Over the course of the study, 16 USGS employees and 3 volunteers were especially helpful with the benthic-invertebrate and fish-community fieldwork associated with this project. Of special note, Brian Caskey and Edward Dobrowolski were the electrofishing specialists; Edward Dobrowolski was essential to collecting the QHEI data; and Amanda Egler was instrumental in collecting and processing the streambed sediments for analysis. 


\section{References Cited}

Benke, A.C., and Wallace, J.B., 1997, Trophic basis of production among riverine caddisflies-Implications for food web analysis: Ecology, v. 78, p. 1,132-1,145.

Britton, L.J., and Greeson, P.E., 1989, Methods for collection and analysis of aquatic biological and microbiological samples: U.S. Geological Survey Techniques of WaterResources Investigations, book 5, chap. A4, p. 151-170.

City of Indianapolis, 2000, Improving our streams in the City of Indianapolis, a report on options for controlling combined sewer overflows: Prepared by Quandt Engineering, Camp, Dresser \& McKee Inc., and Greeley and Hansen Engineers, accessed March 15, 2001, at www.indygov.org/ dpw/cso/cso plan/index.htm.

City of Indianapolis, 2007, Wastewater management: Department of Public Works, accessed April 29, 2008, at http://www.indygov.org/eGov/City/DPW/Environment/ Wastewater/home.htm.

Crawford, C.G., Wangsness, D.J., and Martin, J.D., 1992, Recovery of benthic-invertebrate communities in the White River near Indianapolis, Indiana, USA, following implementation of advanced treatment of municipal wastewater: Archiv für Hydrobiologie, v. 126, p. 67-84.

Crowder, L.B., 1990, Community Ecology, in Schreck, C.B., and Moyle, P.B., eds., Methods for fish biology: American Fisheries Society, Bethesda, Md., p. 609-632, accessed June 19, 2003, at www.fisheries.org/publications/catbooks/ mfb.htm.

Hilsenhoff, W.L., 1987, An improved biotic index of organic stream pollution: Great Lakes Entomologist, v. 20, no. 1, p. 31-39.

Hoggatt, R.E., 1975, Drainage areas of Indiana streams: U.S. Geological Survey, Water Resources Division, 321 p. (Also available at $h t t p: / / w w w . i n . g o v / d n r / w a t e r / 4936 . h t m$.

Landrum, P.F., and Robbins, J.A., 1990, Bioavailability of sediment-associated contaminants to benthic invertebrates, in Baudo, R. Giesy, J.P, and Muntau, H., eds., SedimentsChemistry and toxicity of in-place pollutants: Ann Arbor, Mich., Lewis Publishers, p. 237-264.

Meador, M.R., Cuffney, T.F., and Gurtz, M.E., 1993, Methods for sampling fish communities as part of the National Water-Quality Assessment Program: U.S. Geological Survey Open-File Report 93-104, 40 p.
Medeiros, C., Leblanc, R., and Coler, R.A., 1983, An in situ assessment of the acute toxicity of urban runoff to benthic macroinvertebrates: Environmental Toxicology and Chemistry, v. 2, p. 119-126.

Nelson, J.S., Crossman, E.J., Espinosa-Pérez, H., Findley, L.T., Gilbert, C.R., Lea, R.N., and Williams, J.D., 2004, Common and scientific names of fishes from the United States, Canada, and Mexico (6th ed.): Bethesda, Md., American Fisheries Society, Special Publication 29, 386 p.

Newman, J.E., 1966, Bioclimate, in Lindsey, A.A., ed., Natural features of Indiana: Indianapolis, Indiana Academy of Science and Indiana State Library, p.171-180.

Ohio Environmental Protection Agency, 1989a, The Qualitative Habitat Evaluation Index (QHEI) - Rationale, methods, and application: Ohio Environmental Protection Agency [variously paged].

Ohio Environmental Protection Agency, 1989b (1st update), Biological criteria for the protection of aquatic lifeVolume III, Standardized biological field sampling and laboratory methods for assessing fish and macroinvertebrate communities: Ohio Environmental Protection Agency [variously paged].

Paul, M.J., and Meyer, J.L., 2001, Streams in the urban landscape: Annual Review of Ecology and Systematics, v. 32, p. 333-365.

Pratt, J.M., Coler, R.A., and Godfrey, P.J., 1981, Ecological effects of urban stormwater runoff on benthic macroinvertebrates inhabiting the Green River, Massachusetts: Hydrobiologia, v. 83 , p. $29-42$.

Radtke, D.B., 2005, Bottom-material samples (ver. 1.1): U.S. Geological Survey Techniques of Water-Resources Investigations, book 9, chap. A8, accessed January 24, 2008, at http://water.usgs.gov/owq/FieldManual/Chapter8/ index.html.

Renn, D.E., 1998, Benthic-invertebrate and streambed-sediment data for the White River and its tributaries in and near Indianapolis, Indiana, 1994-96: U.S. Geological Survey Open-File Report 98-533, 159 p.

Rochfort, Q., Grapentine, L., Marsalek, J., Brownlee, B., Reynoldson, T., Thompson, S., Milania, D., and Logan, C., 2000, Using benthic assessment techniques to determine combined sewer overflow and stormwater impacts in the aquatic ecosystem: Water Quality Research Journal of Canada, v. 35, no. 3, p. 365-397. 
Shelton, L.R., and Capel, P.D., 1994, Guidelines for collecting and processing samples of stream and sediment for analysis of trace elements and organic contaminants for the National Water-Quality Assessment Program: U.S. Geological Survey Open-File Report 94-458, 20 p.

Simon, T.P., and Dufour, Ronda, 1997, Development of index of biotic integrity expectations for the ecoregions of Indiana-V. Eastern Corn Belt Plain: Chicago, Ill., U.S. Environmental Protection Agency, EPA 905/R-96/002, $68 \mathrm{p}$.

State of Indiana, 1996, Combined sewer overflow strategy: Indiana Department of Environmental Management, Office of Water Quality, Pretreatment and Urban Wet Weather Section, CSO group, $15 \mathrm{p}$.

U.S. Environmental Protection Agency, 1999, Combined sewer overflows - Guidance for monitoring and modeling: EPA 832-B-99-002 [variously paged], accessed January 23, 2008, at http://www.epa.gov/npdes/pubs/sewer.pdf.

Voelker, D.C., 2004, Biological assessment of streams in the Indianapolis metropolitan area, Indiana, 1999-2001: U.S. Geological Survey Water-Resources Investigations Report 03-4331, 48 p. (plus CD-ROM with appendix data).

Voelker, D.C., 2012, Biological assessment and streambed sediment chemistry of streams in the Indianapolis metropolitan area, Indiana, 2003-2008: U.S. Geological Survey Scientific Investigations Report 2012-5096, 53 p.

Voelker, D.C., and Renn, D.E., 2000, Benthic invertebrates and quality of streambed sediments in the White River and selected tributaries in and near Indianapolis, Indiana, 1994-96: U.S. Geological Survey Water-Resources Investigations Report 99-4276, 52 p.

Woods, A.J., Omernik, J.M., Brockman, C.S., Gerber, T.D., Hosteter, W.D., and Azevedo, S.H., 1998, Ecoregions of Indiana and Ohio: Scale, 1:1,500,000, accessed January 24, 2008, at ftp://ftp.epa.gov/wed/ecoregions/oh_in/Ohio_eco_ lg.pdf. 

